\title{
The Form of Dante's "Libello" and its Challenge to Petrarch
}

\section{Germaine Warkentin}

What questions arise when we compare the form of the Vita Nuova with that of Petrarch's Canzoniere? Perhaps the first should be "what form?" For though it is usual to acknowledge the likeness between the two works, to call the Canzoniere as Adolfo Jenni does, "una seconda Vita Nuova (ma per quasi tutta una vita) interamente in versi," 1 this brief statement alone contains two qualifications, one about content and the other about form, which positively demand that we confront not the resemblances between the two works, but their obvious differences. Can the Vita Nuova and the Canzoniere be said in any real sense to belong to the same class of work? When the question of genre is raised, the links between Petrarch's lyric collection and the European sonnet sequence are apparent. But the Vita Nuova is not a sonnet sequence, and it is only by doing some violence that one can apply to it the generic term "canzoniere," which I have concluded, after long debate, is most appropriate for that type of work.

Yet as Jenni's observation makes clear, the two works are linked in such a way that the shape of the Canzoniere seems not merely a commentary on the shape of the Vita Nuova, but a critique of it as well. The problem this tension poses is of some importance to those of us outside Italian studies who need to deal with issues in our own literature raised by the influence of both collections, and those descended from them, as for example Ronsard, Sidney, and Shakespeare. To produce a historically developed description of the genre they represent has been a goal of mine for some years. But to do so we have to face one of the most fiery - and, I think, illuminating - of its cruces: the influence of the form of the Vita Nuova on the Canzoniere.

The originality of the Vita Nuova is profound. ${ }^{2}$ It is usual to note the resemblance of its mixed verse and prose to two types of work well known to Dante, the prosimetrum, as exemplified for example in Boethius, and the Provençal manuscript chansonnier, with its lyrics surrounded by prose vidas and razos. In actuality, there is little in

\section{QUADERNI d'italianistica Volume II No 2, 1981}


earlier writing to which Dante could have gone for anything more than the lumber to construct his edifice. Boethius offered Dante an important philosophical dimension and the example of a reflective use of the first person, but his poems are not linked to his prose by the interpretative devices with which Dante weaves his together, and throughout they are subordinated to the much more important prose dialogue. The Provençal chansonniers offered of course the tradition of amorous vernacular lyric of which the Vita Nuora exemplifies a later phase, but with one possible exception there is no such chansonnier organized as a single work by the author of its poems. The basis for the unified lyric collection, canzoniere, or sonnet sequence was laid when Dante brought elements from all of these - prose and verse carefully integrated with each other, an ambitious philosophical perspective, intense subjectivity, and a coherent body of erotic metaphor - under the control of a single conception. I shall argue here, however, that the genre's eventual shape resulted from Petrarch's essentially antagonistic response to this synthesis.

The Vita Nuova is composed of a group of subjective amorous lyrics set in a prose matrix. The prose on one hand narrates the events of an amorous experience of which the poems record crucial moments, and on the other tells us something about how to read those poems. The lyrics are skillfully organized as well to display the generic resources of each type of poem within a larger aesthetic structure; unlike preceding manuscript collections of lyrics, ${ }^{3}$ the Vita Nuova disperses single canzoni among groups of sonnets, and devises out of this variation of genres a pyramidal structure which displays the forms in a hieratic scheme pivoting on the central canzone "Donna pietosa e di novella etate."

The raising of such a structure is dependent from the beginning on Dante's awareness of the contrast between the potentialities of these component genres (and their related prose) and of the possibility of controlled variation in the interests of a larger effect. That larger effect is the construction of an itinerarium, a journey of the lover from the first moments of his love, through sorrow, to the "intelligenza nova" of VN XLI. It is this conscious awareness of the diversity of formal elements to be controlled that differentiates the Vita Nuova as a lyric collection from on one hand, the miscellaneous chansonniers with their rigid groupings of poems by author and genre, and on the other hand the sonnet narrative the Fiore, or the contemporary sequences of sonnets arranged according to external schemata or in mere epistolary clusters. ${ }^{5}$

It is possible that Dante's near contemporary the troubadour Guiraut Riquier (1230-1290?) made the same leap of the imagina- 
tion. In MS. BN Fr. 856 (a fourteenth-century manuscript known to have been produced in Provence and to have remained there for many years) his lyrics are grouped purely by genre, but each is given its cagione in the form of the date on which it was written, and in several places comments have been included on the prosody of the poems. These words appear at the beginning:

Thus begin the songs of Guiraut Riquier of Narbonne in this manner: with cansos and verses and pastourelles and retrouenches and descorts and albas and other diverse works and thus arranged as it was ordered in his own book. Which book, written in his own hand, was all thus copied, and says what is listed above. ${ }^{\circ}$

"Lo sieu libre," says the scribe: the poet's own book. It would be interesting to know if Guiraut actually did arrange his own book, which has not only the generic order outlined above, but a moral one as well (like Petrarch's Canzoniere, it ends with a hymn to the Virgin). What is more important, however, is that some nearcontemporary thought he had, and thus documented what is of central interest for Dante's imaginative leap: acceptance of the idea that such a book could be put in order by the author himself, and that this order might exemplify by its form his vision of his own creativity. The great unacknowledged likeness between the Vita Nuova and the Canzoniere is in their shared commitment to this kind of program for arranging lyrics. In both cases an intense awareness of the resources of genre is deployed to structure a collection in which the poet daringly acknowledges himself as auctor and - more daringly yet - as text as well. In the genre of the canzoniere from Dante to, I would venture, George Herbert's The Temple, the poet functions both as the maker, the auctor of his book, and in effect as the material of the book itself.

Under the guidance of Judson Allen, Paul Zumthor, Eugene Vance, Malcolm Parkes and A.J. Minnis? we have recently become sensitive to the increasing importance of the human, rather than the Divine auctor in the literary and scholarly activity of Dante's century. Minnis detects its first symptoms in the "Aristotelian prologue" of the thirteenth-century commentators. There, the Aristotelian scheme of four causes which were thought to give rise to a written work made it possible to consider, under the heading "causa formalis" the method of treatment adopted by the human auctor in handling his material, his modus tractandi or modus agendi. "In the Aristotelian prologue," writes Minnis, "the modus agendi was redefined as the way in which the individual human auctor had chosen to express his personal revelation."8 Such a system made it possible to discuss the differences in literary method and style 
that individuated authors, and consequently made writers themselves more aware of their own authorial personalities. Statements both by St. Bonaventure and St. Thomas exemplify this new perspective. St. Bonaventure recognizes the proprietorship of the auctor over his own work, and St. Thomas the subjectivity which may be one of the permitted formal causes of that work. 9

In the famous opening passage of the Vita Nuova Dante describes the book of his memory - the libro which is co-extensive with all that he knows of his life - and the little book, the libello, of which the first words, "Incipit Vita Nova" constitute a rubric announcing this section, this new life, as a division in a larger work. Here the " $\mathrm{I}$ " of the poems is conceptualized first as a source of matter, and secondly as imposer of order upon that matter. Singleton as a result argues that the Vita Nuova would have seemed to a thirteenthcentury reader like a volume of poems with two glosses: Dante has copied from the book of memory poems which he once wrote, and around which a first gloss has been written by another hand, that of God. Dante then transforms himself from scribe to commentator, and adds the second gloss, which includes for example the divisioni, Chapter XI, and Chapter XXIX.10 If we follow St. Bonaventure, however, we can take this a step farther, for the Saint distinguishes very conveniently the roles which seem to be taken on in the Vita Nuova. A scribe, he says, is one who copies the writings of others, adding and changing nothing. A compiler, on the other hand, copies the writings of others, adding material, but not his own. A commentator is he who copies his own and others' writings, but chiefly those of others, and only adds his own in the form of notes and appendixes. Finally, there is the auctor. He copies his own and others' writings, but his own take the principal place, and those of others are appended as confirmation of what he writes. ${ }^{11}$ It is this proportion which is clearly maintained in the Vita Nuova. Dante is certainly scribe, and certainly chiosatore. But he is the author of both of the poems and the second gloss, and if the first gloss comes from God's book of the Universe, we must remember the pains Dante takes here and in the Commedia to make clear the likeness between the poet's art and the Creator's.

This likeness is implied in the relationship of libello to libro, which is not that of part to whole, but rather of model to original. That is, the libello stands in analogical relationship to its subject-matter. Through the agency of the body of spiritualized erotic metaphor afforded by contemporary amorous lyric, the libello of the "new life" is made to illuminate the libro of life itself. This dextrous act is made possible by Dante's confidence in the figure of analogy to organize experience. The libello, like the later Commedia, reveals the 
structure of the cosmos as he believes it to be constituted, though in the Vita Nuova that cosmos has the charm of a miniature. The book in which it is exemplified is not the great volume of Paradiso 33, which through the agency of love binds up that which flutters through the universe like the Sibyl's scattered leaves, but one much simpler and more youthfully conceived. But the tripartite structure revolving around a central canzone, the three-stage progress of the soul from a lower to a higher state of being, and the cognitive function of the prose, all exemplify the serenity of a vision in which the experienced and transcendental worlds can be contained in a single and supremely expressive figure. For Dante, this figure has to make clear both the love of God for His creation, and the tendency of that love to explicate itself, to make itself intelligible. In the Commedia this love, endlessly explicated, binds up the scattered leaves. In the youthful libello, the poet is permitted a share in this creative power, as he shows so delightfully when he thinks of what his own poetic prowess might do: "Farei parlando innamorar la gente," (VN, XIX). The very ending of the libello itself is contrived to remind us of this, for when Dante after his miraculous vision resolves "di non dir piú di questa benedetta, infino a tanto che io potessi piú degnamente trattare di lei," he does so in order to prepare himself for the yet greater creative task, "di dire di lei quello che mai non fu detto d'alcuna." And in that act the "Sire della cortesia" of the youthful miniature will be transformed into "L'amor che move il sole e l'altre stelle."

I can say nothing here about Petrarch's reading of, and antagonism to, Dante that has not already been said by others. ${ }^{13}$ What I can do is focus the elements of that envious, yet emulative response on the generic issues already raised. In the Vita Nuova Dante, I have suggested, fused into a new kind of work a number of disparate elements, and his synthesizing gesture was made with a very creative awareness of the new prerogatives of the authorial role. Petrarch's Canzoniere constitutes a response to this new kind of work, one dominated by three leading motifs: a fundamental literalism, a classicising aesthetics, and a need to distance himself from his great predecessor which resulted in an apparent suppression of his image in Petrarch's works. In Harold Bloom's terms Dante was that poet with whom Petrarch had to struggle in order to become himself, and the consequence of such a struggle, as Bloom shows, is a willed repression of the original which paradoxically leaves its spectral traces everywhere in the later poet's work.14

Thus it is that in Petrarch's hands the lyric collection extends itself to cover the whole life of the poet, a structuring schema is at 
the same time asserted and denied, and the narrative and analytical functions of the prose are absorbed into the lyrics themselves to produce not the explication of a text, but a continuous interior debate on its very validity. This disruption of the governing coordinates of Dante's synthesis results in a more than Dantean focus on the persona of the auctor, a focus which Petrarch skillfully dramatizes by keeping in constant doubt the status of the text which the poet both is and is making. His reasons for doing so he made clear in the well-known letter to Pandolfo Malatesta of 1373, in which he explained that the structural variety of the Canzoniere was the result of the "instabilis furor amantium" which its lyrics express. ${ }^{15}$ With characteristic literalism he turned away from Dante's analogical vision to transform the physiological condition of lovesickness as it was understood by the doctors of his age into a vision of the moral self. 10 He achieved this by making the fragmentation, the varietas of the book its very modus tractandi.

Thus when the psychomachia between Amor and Virtute results in a victory for unreason, it marks the poet's submission to a love which expresses itself as a disruption of the poetic process:

Piú volte incominciai di scriver versi: ma la penna et la mano et l'intellecto rimaser vinti nel primier assalto. $(X X)$

When he can write, the poems he produces are the rime sparse announced in sonnet 1 , the scattered rhymes that not only recall the fragments mentioned in John 6:12, but constitute a pointedly ironic allusion to Dante's "ció che per l'universo si squaderna." The poems in their isolation one from another mirror the fragmentation of their creator. They are "seguaci de la mente afflicta," and Petrarch makes their resistance to the imposition of a modus tractandi an integral part of the drama: "Quai fien ultime, lasso," he writes, "et qua' fien prime?" (CXXVII). The solitude of individual poems is restated in the solitude of the poet himself. Isolated by shame and regret, he can conceive of himself only as that most reductive of literary kinds, the favola al popolo tutto of his opening sonnet.

As this suggests, Petrarch's libello is not a model of the cosmos, like the Vita Nuova, but a model of the worldly, limited human psyche. In the Vita Nuova, a unifying method naturally emerges from Dante's metaphorically conceived universe. The Canzoniere however comprises a series of infinitely anxious discriminations. Just as the poet separates himself from "il popol tutto," so also he asks, "S'amor non è, che dunque è quel ch'io sento?/Ma s'egli è 
amor, perdio, che cosa et quale?" (CXXXII). Instead of the continuity of the itinerarium, Petrarch offers the dissidio, that separation of the moral self into its parts which leaves him in perpetual search of the upward movement that might reconcile them. As Giuseppe Mazzotta notes, 17 each of Petrarch's lyrics is a new attempt at that upward movement. Each new beginning - precisely because it starts again - recreates the rupture yet once more. From these many beginnings, only one possible ending can result. Where Dante's libello prepares him for his greatest creative task, Petrarch must, in his concluding canzone, swear to the Virgin,

\footnotetext{
Se dal mio stato assai misero et vile per le tue man resurgo,

Vergine, i'sacro et purgo

al tuo nome et pensieri e 'ngegno et stile,

la lingua e 'l cor, le lagrime e i sospiri.
}

In this consecration, this purging, the gathering of fragments must be set aside for good; no continuity can link the old man with the new.

As an organizing principle, the concept of varietas is thus a defiant repudiation of Dante's hieratic schema in the Vita Nuova. Yet as I have shown elsewhere, varietas is an accepted classical aesthetic principle, endowing the works which employ it with an elegant plasticity of organization. ${ }^{18}$ And the term "variety" was used well into the seventeenth century to describe the plenitude of creation. Thus varietas brings with it the implication of order and fullness as well as the disorder of the instabilis furor amantium and the rhymes, scattered like the Sibyl's leaves, which result from it. This paradox is not ignored in the Canzoniere, which alludes persistently to metaphor and correspondence as modes of comprehension. Though the poems are scattered, there are 366 of them, a calendrical allusion of obvious importance. The exploitation of the number six, the number of mortality, is equally self-conscious. The earthly Laura is eventually transcended in the "Vergine bella" (vera beatrice, also) of the final canzone. The passionate moral certitude of the Babylonian sonnets and Italia mis, the very faith in the power of prayer at the end - all afford an alternative perspective on the drama of doubt with which the Canzoniere is preoccupied.

This double perspective can be seen even in the way Petrarch takes on the role of auctor. Petrarch views his whole life, in all its abundant diversity, as a text. But because this text is a fragmented one, he has to take on himself the entire burden of validating its vision. His task is not, as it is for Dante, to discover the style of 
praise and thus exemplify the operations of the creating word, but to conquer his solitude and that of the poems by the heroic exercise of eloquence in the world of man. Thus his choice of the frailest and most vulnerable image of the poet's book, his renunciation of the libello for rime sparse, is only one aspect of his theme. Insofar as the work scatters its resources, not unified by analogy or by such cognitive devices as the prose, it is a mimesis of the poet's suffering in love. Insofar as it makes his pain intelligible to men through its eloquence, it constitutes a triumph over it. In part because of the history of the work's evolution, this goal slips in and out of focus in the Canzoniere. But in Book IX of the Africa, Petrarch makes his point clear in the prophecy of his future poetic role which Homer vouchsafes to Ennius; there the poet Franciscus is described as gathering together Scipio's exploits into a single poem: "Francisco cui nomen erit . . corpus in unum stringet."19

Of the many dualities of the Canzoniere, the most human perhaps is its attempt to conquer by its own supreme mastery of structure the great architect Dante. Dante's libello is Petrarch's rime sparse, his itinerarium Petrarch's dissidio, his eternally creating word Petrarch's earthly, temporal laurel. But the self-conscious variation extends even further. In the Vita Nuova Dante, yet to become the greatest of exiled poets, portrays himself as a citizen, if only of the small circle of the elect. Petrarch is a solitary; within the historical fact of Dante's exile, he makes himself a greater exile yet. If memory is a book for Dante, it is a mere thread for Petrarch, and necessarily so, since his experience is conceived as a labyrinth. The Vita Nuova presents us with a city, one populated chiefly by beautiful ladies and "famosi trovatori" but a human scene nonetheless. In the Canzoniere Petrarch retreats to nature. "Solo e pensoso," he wanders the empty fields, fleeing every trace of man, and followed only by Love. Dante grows towards his Beatrice; in the Canzoniere it is Laura who changes and Petrarch who remains static, ever the sinner, graying though he may be. And Dante's confidence in language is countered by Petrarch's linguistic duplicity, in which every form of words seems at the same time to state and negate, and the search for eloquence produces a language so packed with allusion that a single word can flower with three, four, and five meanings.

That the Canzoniere, rather than the Vita Nuova eventually served as the master-exemplar of the Renaissance lyric collection is a consequence (fittingly enough) of its duality. Both Dante and Petrarch adopted the new role of auctor in such a way as to open its thematics, as well as its method, to their emulators, but Petrarch transformed the lover's self-examination into an open-ended task 
well adapted to the searching age to come. Yet as poet after poet took up what Minturno in one of his sonnets was to call "l'opra del mio pianger," 20 the continual re-statement which this openendedness made possible led to a refocussing of the notion of the libello. Petrarch's scattered rhymes compose a series of individual attempts at the consolidation of multiple aesthetic materials, and into each one is packed immense possibilities for invention by poets increasingly aware of classical techniques of composition. Whether Petrarch was using with a full sense of its classical authority the topical method of composition or whether, with what he admitted was an imperfect knowledge of the ancient rhetoricians he was simply feeling his way towards it, for many of his heirs the Canzoniere functioned quite literally as a commonplace book, 21 in which all that could be said about love was collected in a single topos or "place," ready for their art to unpack. Petrarch's tense response to Dante in the long run resulted in the transformation of the libello or poet's book from an analogy for the order of God's creation into the image of a profoundly human enterprise. ${ }^{22}$

\section{Victoria College}

University of Toronto

\section{NOTES}

1 Adolfo Jenni, "Un Sistema del Petrarca nell' ordinamento del 'Canzoniere'," in Studi in onore di Allherto Chiari (Brescia, 1973), Il, 721-732; p. 721.

2 Domenico de Robertis, for example, refers to it as "il primo libro della nostra letteratura": Il Libro della "Vita Nuova" 2nd ed., expanded. (Firenze, 1972), p. 5. And Barbara Nolan states forthrightly, "The Vita Nuora has no predecessor or successor in mediaeval literature": "The Vita Nuova: Dante's Book of Revelation," Dante Studies, 88, (1970), 51-77; p. 51.

3 E.H. Wilkins, The Making of the Canzoniere and other Petrarthan Studies (Roma, 1951), pp. 265-6, suggests that this arrangement was originated by Petrarch, but it is clear that the Vita Nuora, when considered as a lyric collection, also employs it, though on rather different principles, and in actuality there are exceptions in other early manuscripts, though they are probably the result of accident rather than artistic design.

4 See the brief review of various schemes by Mario Pazzaglia, "Vita Nuova," in Enciclopedia Dantesca (Roma, 1976), V, 1088.

5 It seems necessary to make this point because of the eventual transformation of "canzoniere" into "sonnet sequence" in Italy as well as in England and France, which has resulted in a certain amount of reasoning backward in an attempt to account for the genre.

6 Ms. B.N. Fr. 856, 288: "Aissi comensan li can d'en Guiraut Riquier de Narbona enaissi cum es de cansos e de verses e de pastorellas e de retroenchas e de descortz e d'albas e d'autras diversas obras enaissi adordenadamens cum era adordenat en lo sieu libre, del qual libre escrig per la sua man fon aissi tot translatat e ditz enaissi cum desus se conten." The collection is also found in Ms. B.N. Fr. 22543. See Riquier, Las Consos, ed. Ulrich Mölk, Studia romanica, 2 (Heidelberg, 1962). 
7 Judson Allen, "Commentary as Criticism: Formal Cause, Discursive Form, and the Late Mediaeval Accessus," in Acta Conventus Neo-Latini Lovaniensis, Proceedings of the First International Congress of Neo-Latin Studies, Louvain, 23-28 August 1971 ed. J. IJsewin and E. Kessler (Louvain, 1973), pp. 29-48; Paul Zumthor, "Autobiography in the Middle Ages?" Genre, 6 (1973), 29-48; Eugene Vance, "Love's Concordance: The Poetics of Desire and the Joy of the Text," Diacritics 5, No. 1 (1975), 40-52; Malcolm B. Parkes, "The Influence of the Concepts of Ordinatio and Compilatio on the Development of the Book," in Mediaeval Learning and Literature; Essaus Prisented to Richard William Hunt, ed. J.J.G. Alexander and M.T. Gibson (Oxford, 1976), pp. 115-141; A.J. Minnis, "Discussions of 'Authorial Role' and 'Literary Form' in Late-Mediaeval Scriptural Exegesis," Beitrage zur Geschichte der Deutschen Sprache und Literatur, 99 (1977) No. 1, 37-65.

8 Minnis, p. 41 .

9 Minnis, p. 42, citing St. Thomas, In Epistolam ad Romanos cap. 1, lect. 1, and p. 44, citing St. Bonaventure, (In primum librum sententiarum), proem. qu. 4, conclusio.

10 C.S. Singleton, An Essay on the Vita Nuova (Cambridge, 1949), pp. 52-3.

11 Minnis, p. 44, and see Parkes, pp. 127-8.

12 See Piero Boitani, "The Sibyl's Leaves: A Study of Paradiso XXXIII," Dante Studies, 96 (1978), 83-147.

13 See for example; Aldo Bernardo, "Petrarch's Attitude Toward Dante," PMLA, 70 (1955), 488-517; the argument and review of the problem by Marco Santagata, "Presenze di Dante 'Comico' nel 'Canzoniere' del Petrarca," GSLI, 146 (1969), 163-211; and Sara Sturm-Maddox, "Transformations of Courtly Love Poetry: Vita Nuova and Canzoniere," in The Expansions and Transformations of Courtly Literature, ed. Nathaniel B. Smith and Joseph T. Snow (Athens, Ga., 1980), pp. 128-40. See also G.W. Pigman, Jr., "Versions of Imitation in the Renaissance," Ren.Q., 33 (1980), 1-32.

14 See the general argument of Bloom's The Anxiety of Influence (New York, 1973). In Bloom's terminology, of the six "revolutionary ratios" in which the work of a later poet can stand to that of an earlier, Petrarch's reaction to Dante would be that of askesis: "The later poet does not, as in kenosis, undergo a revisionary movement of emptying, but of curtailing; he yields up part of his own human and imaginative endowment, so as to separate himself from others, including the precursor, and he does this in his poem by so stationing it in regard to the parent-poem as to make that poem undergo an askesis too; the precursor's endowment is also truncated," (p. 15). Bloom (p. 7) quotes Wallace Stevens' letter to Richard Eberhart asserting his attempt to detach himself from the influence of Eliot and Pound; Stevens' words uncannily echo those of the famous letter to Boccaccio in which Petrarch contended he tried not to read Dante when he was forming his style (Fam. XXI, 15). For another application of Bloom's theory to Petrarch see Marguarite R. Waller, Petrarch's Poetics and Literary History (Amherst, Mass., 1980) which came to hand shortly after this paper was written and presented. A different approach to the same kind of problem in Petrarch is taken in Thomas M. Greene's "Petrarch and the Humanistic Hermeneutic," in Italian Literature: Roots and Branches. Essays in Honor of Thomas Goddard Bergin, ed. Giose Rimanelli and Kenneth John Atchity (New Haven and London, 1976), pp. 201-24.

15 Petrarch, Variae, ix.

16 As I have argued more fully in "Love's sweetest part, variety': Petrarch and the Curious Frame of the Renaissance Sonnet Sequence," Renaissance and Reformation, XI (1975), 14-23.

17 Giuseppe Mazzotta, "The Canzoniere and the Language of the Self," SP, 75 (1978), 271-96; p. 295.

18 See note 16 , above.

19 Petrarch, Africa IX, 238-40.

20 Antonio Sebastiani, "Minturno," Rime ef Prose. Ed. G. Ruscelli (Venice, 1559), Rime II, ii. 
21 That topical methods of composition may have facilitated copin in sonnet-writing has already been hinted at by Sister Joan Marie Lechner, Renaissance Concepts of the Commonplaces (New York, 1962), p. 110.

22 And, it is probable, yet further solitude. Hans Robert Jauss notes, "The selfsubmersion of the solitary reader in a book as work - that is so self-satisfying that it 'means the world' for him - can describe the particular experience of autonomous art in the bourgeois era": "The Alterity and Modernity of Mediaeval Literature," in New Liternry History, X, (1979), 181-227; p. 189. 